\title{
Selection the Basic Lean Manufacturing Techniques in Developing the Model for Industry 4.0 in Kosovo Manufacturing Industry ${ }^{+}$
}

\author{
Fatmir Azemi ${ }^{1}$, Roberto Lujić ${ }^{2}$, Goran Šimunović ${ }^{2}$ and Daniel Tokody ${ }^{3, * \mathbb{C}}$ \\ 1 Mechatronics Management Department, University for Business and Technology, Lagjja Kalabria, 10000 \\ Prishtinë, Kosovo; fatmir.azemi@ubt-uni.net \\ 2 Mechanical Engineering Faculty in Slavonski Brod, JJ Strossmayer University of Osijek, Trg Ivane Brlić \\ Mažuranić 2, 35000 Slavonski Brod, Croatia; rlujic@sfsb.hr (R.L.); goran.simunovic@sfsb.hr (G.Š.) \\ 3 Doctoral School on Safety and Security Sciences, Óbuda University, Népszínház utca 8., \\ 1081 Budapest, Hungary \\ * Correspondence: tokody.daniel@dosz.hu; Tel.: +36-309-507-193 \\ + Presented at the 14th International Conference on Interdisciplinarity in Engineering-INTER-ENG 2020, \\ Târgu Mureș, Romania, 8-9 October 2020.
}

Published: 31 December 2020

\begin{abstract}
Recently, there have been done numerous investigations related to lean manufacturing techniques. However, very little has been reported about the implementation and selection of lean manufacturing in the Kosovo manufacturing industry. This article presents the application of lean tools through Kosovo manufacturing industries and the selection of the most useful lean techniques for developing a model for an innovative smart Kosovo enterprise which is our initiative in the process of preparing Kosovo enterprises for the new age of industry-Industry 4.0. After several visits through Kosovo enterprises, the literature review has noticed that there is no investigation in the selection and implementation of lean techniques and tools in Kosovo enterprises. The purpose was to understand how Kosovo manufacturing enterprises use lean techniques and which are the most useful techniques. Analyses have been done based on interviews and questionnaires. Seven basic lean techniques are selected based on the response from the questionnaire and representing basic lean tools for developing a model of a production system regarding Industry 4.0.
\end{abstract}

Keywords: Industry 4.0; innovative smart enterprises; Kosovo manufacturing industry; lean manufacturing techniques

\section{Introduction}

Origination in Japan, particularly at Toyota, a carmaker in the 1960s developed the principles of lean production/manufacturing. The lean manufacturing approach is about the reducing or elimination of waste or activities which add no value to the manufacturing process. Therefore, lean manufacturing is a management philosophy based on the Toyota Production Systems (TPS) [1].

In this paper, the investigation is to continue the work of our initiatives for developing a model for innovative smart enterprise in the Kosovo industry regarding Industry 4.0 [2,3]. Specifically, which are the most useful lean techniques for innovative smart Kosovo enterprises is the main issue of this investigation. The questionnaire is used to collect data from manufacturers on the use of lean methods and implementation within Small and Medium Enterprises (SMEs) in the Kosovo manufacturing industry. From questionnaires and interviews with experts in the industry, the aim is to understand common challenges that companies face when implementing or have implemented lean manufacturing techniques/practices in their facilities and select the most useful lean tools for Kosovo enterprises. 
Many investigations have been done all around the world in the field of lean manufacturing and many of the authors have given solutions, but in the Kosovo manufacturing industry, a gap exists in this direction.

This study provides a brief description and explanation of which lean principles are used within SMEs of the Kosovo manufacturing industry, provides approaches on how to select the best lean tools for Kosovo enterprises, and identifies the most useful lean tool implications on systems by producing exactly what the customer wants, at the minimum cost with minimum or zero defects. So, the main reason of this study is to fulfil gaps in the developing model for smart enterprises in the aspect of the organization. Each manufacturing company has a unique system of manufacturing and recently some countries are in the process of developing their model for the new era of industry, such as Industry 4.0 in Germany. In Kosovo, there are no initiatives in this direction and the selection of lean manufacturing principles is too important for developing a model of the enterprise regarding Industry 4.0. The developed model could be implemented and will be unique and original for Kosovo enterprises, especially in SMEs.

Since the main objective of the investigation is to select the most useful lean techniques for developing the model for innovative smart enterprises, the following questions are presented:

- For Kosovo SME manufacturers that are not using lean manufacturing techniques, do they plan to use them?

- For Kosovo SME manufacturers that are not using them and do not plan to use LMTs, why not?

- For Kosovo enterprises that are using lean manufacturing techniques, which ones do they use and when did they start using them?

- For Kosovo enterprises that are using lean manufacturing techniques, which of them are helping the most?

\section{Literature Review and Theoretical Background}

To be successful in a competitive business environment, managers and staff need to know how to organize as well as how to develop product and manufacturing. Lean product development is an approach to organize product development according to a set of techniques/principles and existing different lean manufacturing techniques that are reported by different authors. Studies on the most used and helpful techniques can be found for different countries, but for the Kosovo manufacturing industry, it is not reported. Very little has been reported about the implementation and use of lean manufacturing in the Kosovo manufacturing industry; there are few papers specifically related to the administrative processes.

\subsection{Lean Manufacturing}

The term lean manufacturing was first used by Womack et al. [4] as a 'secret weapon' responsible for quality improvement and elimination of waste, so, the lean manufacturing contributes to cost reduction within organizations. Lean manufacturing according to Detty and Yingling [5] is a comprehensive philosophy for operating, structuring, managing, controlling, and continuously improving industrial production systems. The aim of lean manufacturing is to reduce the waste in inventory, human effort, time to market and manufacturing area to become responsible to demand of the customer while producing products with the highest quality, most economically and efficiently [6].

Shah and Ward [7] supported the above statements while pronouncing that lean production is a multi-dimensional technique that encompasses a wide diversity of management practices, involving quality systems, just-in-time, cellular manufacturing, work teams, and supplier management.

The lean manufacturing goal is to produce just what is needed and when the product is needed. The process of production is pulled according to the downstream processing workstation so that each of the workstations have only produced what is required by the next workstation. Lean manufacturing concentrates on defect-free lines of production [8]. It aims to avoid defects at the beginning and 
for inspection of quality to be performed by the labourers as part of the process in-line production. Lean manufacturing requires attempting perfection by regularly removing layers of waste as they are uncovered. This, on the other hand, requires high level involvement of a worker in the continual improvement process.

According to Melton (2005) [9], the main improvements related to lean were time reduction to customers, efficient usage of processes, less utilization of inventory, improvement of knowledge management, cost savings, and rework reduction. Additional benefits of lean are improving the financial position, achieving competitive advantage, improving services, process standardization, and increasing quality. Some other positive factors are the increasing competence of employees, reducing disappointments with increasing satisfaction of customers, financial benefits to the organization, and faster work completion. In addition, lean manufacturing helps organizations in changing their approach to problem-solving abilities and standardization [10,11]. Moreover, it enables organizations to accomplish competitive advantage concerning high quality and encourages the empowerment of employees, delivery reliability, and faster delivery time.

\subsection{Lean Manufacturing Techniques}

To transform a traditional organization [12] into a lean organization should be made continually essential and take numerous efforts. Several elements have been discussed by researchers and manufacturing organizations have adopted them in the process of production to increase competitiveness in the market by reducing response time to customers, reducing product manufacturing cost, and improving productivity and quality. The following presents key elements which have been used in different research papers.

The $5 \mathrm{~S}$ is a systematic philosophy (approach) aimed at organizing, standardizing, cleaning, ordering, and continuously improving a workplace area. Furthermore, the 5S according to Johannson is identified as part of the technique of green productivity [13].

Six Sigma is a program of management designed to decrease waste and increase productivity. Six sigma, according to Chakravorty [14], has a strong focus on customer satisfaction and meeting customer requirements.

TPM - the technique total productive maintenance (TPM) contributes to the basic preventative maintenance of machines, the breakdown time of equipment and machines is reduced. It also increases the efficiency of operation of the machine as a worker cleans, along with the inspection, lubrication, tightening activity of his machine.

Kanban is a shop floor tool used as an indication to control the release of the materials in operation and communicates customer requirements from downstream to the upstream worker. In such a manner, organizations know to provide more materials from suppliers [15]. Once the product is taken from finished parts against customer requests to recharge the moved quantity, it is replaced by coloured cards or with electronic devices.

SMED/setup time reduction-lean manufacturing aims to reduce setup time and changes over time because it spends critical working time and decreases the operator time and appropriate utilization of the machine.

Kaizen is a method which means small improvement. To keep activities continuously improving throughout the organization, the Kaizen method culture has to be created and preserved. Kaizen commonly is done by the personnel who are directly in the process of production mainly by operators for improvement in working circumstances, safety, productivity, quality, reduction of set up time, or some other small change for improvement.

Value stream mapping is a technique that visually displays the stream of materials and information along the production process. The main aim of value stream mapping is to put side by side activities for both added-value activities and non-added-value activities. 


\section{Methodology}

This investigation project was designed as a questionnaire-survey and interviews with managers to evaluate the most useful lean manufacturing techniques within SMEs in the Kosovo industry. There were 186 questionnaires delivered to companies through email and by hand. Ninety-five questionnaires were answered completely and in the right way and are accepted as the sample size.

So, of the 186 questionnaires sent out, 95 were received as regular or completely answered, the response rate is $51.07 \%$.

The questionnaire was divided into three parts: the general questions, background information about the organization, the usage of lean, benefits, and barriers in the implementation of the LMT (which LMT has helped the most, how important is for a company to use LMT, etc.). In Figure 1, the size of the company is presented (according to the choices presented in the questionnaire).

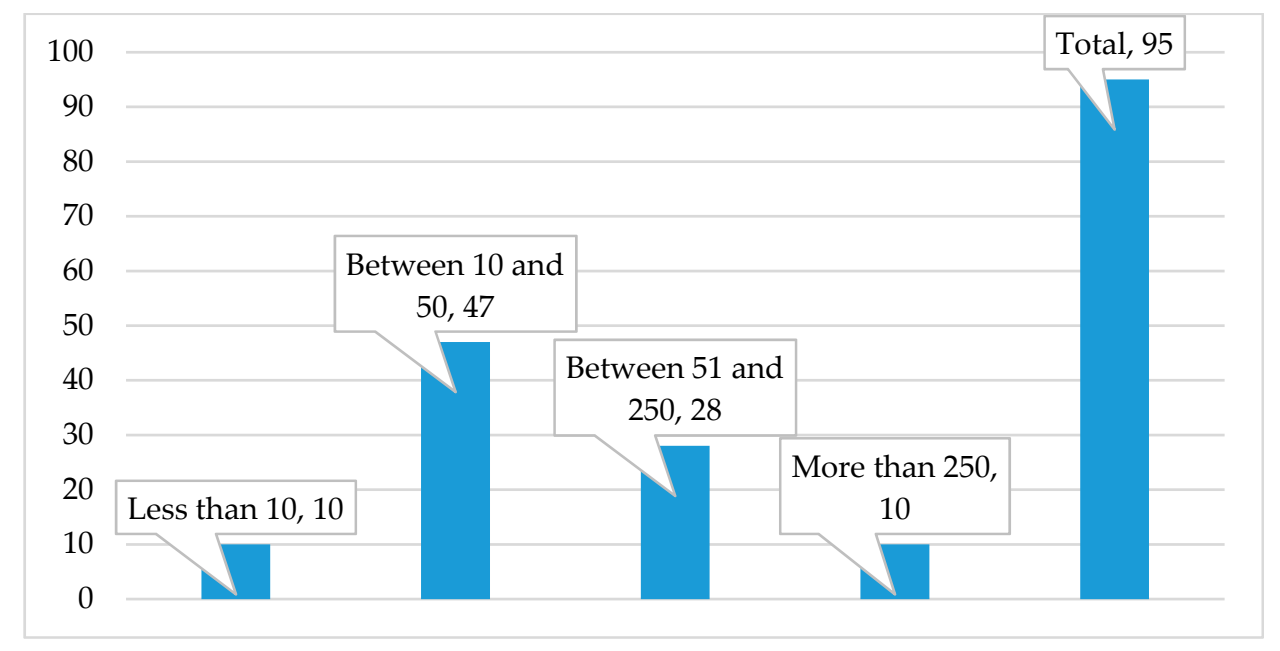

Figure 1. The size of the companies that are included in the survey.

According to the position in the company, the respondents who answered the questionnaires are as below:

- $56.25 \%$ of them are top managers,

- $37.50 \%$ of them are middle managers, and

- $6.25 \%$ of them are employees that have worked on the project.

Whereas, the type of industries which are included in the survey are presented as follows: civil industry (9 companies), food industry (11 companies), metal manufacturing industry (16 companies), general machinery and appliances manufacturing (13 companies), electrical machinery and appliances manufacturing (9 companies), transportation equipment manufacturing-other than automobiles (6 companies), transportation equipment manufacturing-automobiles ( 2 companies), plastic products and/or rubber products manufacturing (11 companies), construction (10 companies), lumber/wooden products manufacturing (14 companies), other manufacturing industries (11 companies).

\section{Results and Discussion}

To summarize data, the descriptive and inferential statistical analyses are done. The basic features of the data are described with descriptive and inferential statistics, spreadsheet and SPSS packet program are used to analyze collected data. The main purpose of this investigation was to determine which are the most used lean techniques and helpful for Kosovo SMEs, which lean tools (techniques) are used by the companies or are still used and so on.

For the companies that are not using lean manufacturing techniques, do they plan to use them? In Figure 2, the percentage of companies is presented that did not use LMTs but were planning to use or 
not to use in the future. The percentage of those who said they did not use LMTs but were planning to was $63.49 \%$ ( 40 of 63 total), and companies that have not planned to use LMTs was $36.51 \%$ ( 23 of 63 total).

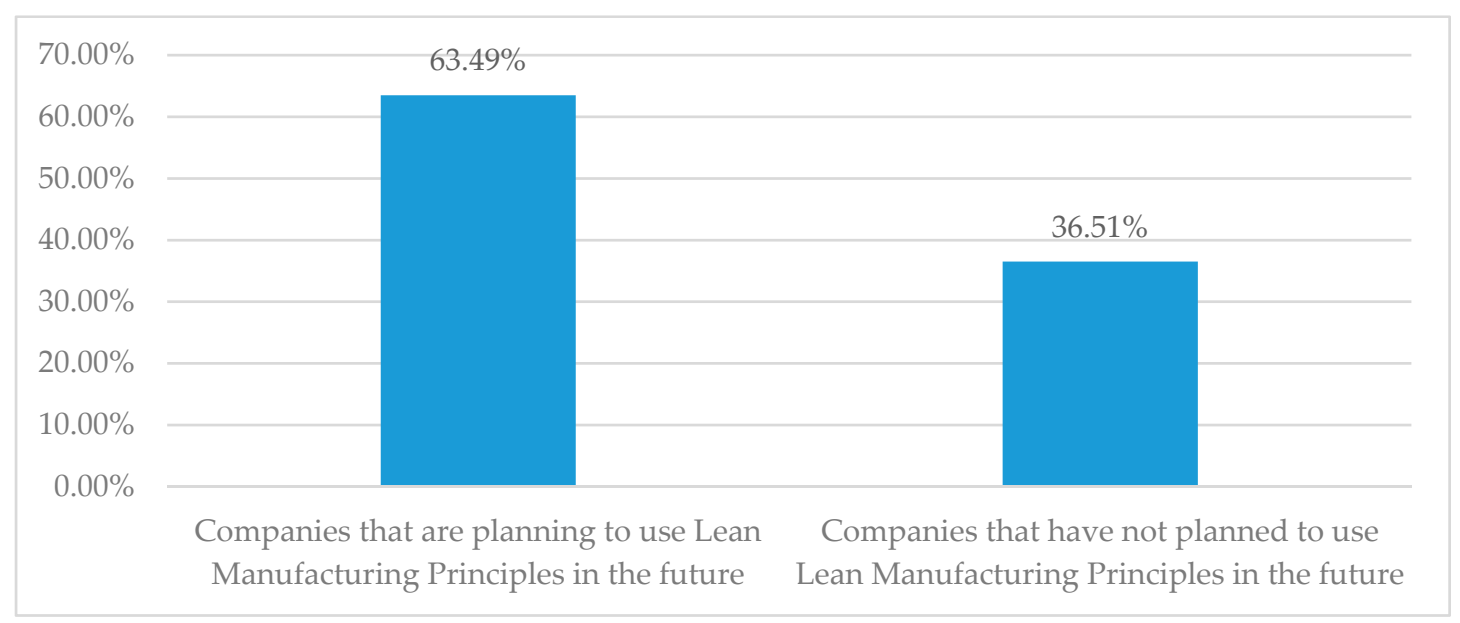

Figure 2. The percentage of companies that plan to use/not planned to use lean manufacturing principles in the future.

For the companies that are not using LMT and do not have a plane to use them, why not? Here are the "reason" percentages for the 23 companies that are both not using LMTs and are not planning to use in the future, the responses are as below:

- We are not informed much about lean manufacturing techniques: $43.48 \%$ (10 companies),

- We understand lean manufacturing techniques but we are not informed how to use them: $39.13 \%$ (9 companies),

- We consider that adopting lean manufacturing techniques will not be beneficial: $17.39 \%$ (4).

Figure 3 below presents lean tools that companies currently are using or have used in their process of manufacturing.

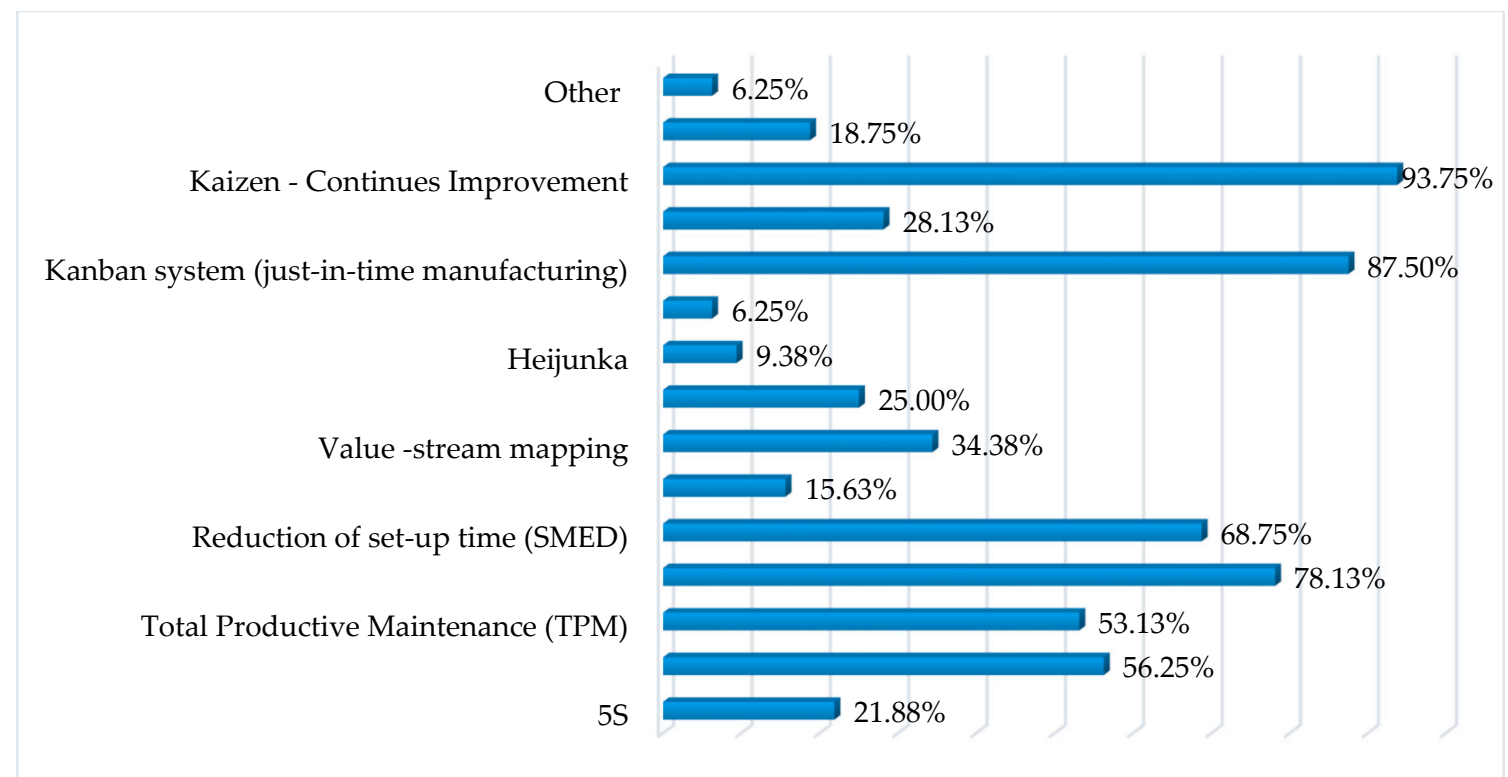

Figure 3. Lean tools that companies are using or have used. 
For companies that use LMTs, when did they start using them? Based on the responses of 32 companies that are using LMTs, the first question was: how long the companies have been using LMTs. Below are given the choices of respondents on the questionnaire along with percentages:

- About six months ago: $3.13 \%$ (1 company),

- Between six months and a year ago: $6.25 \%$ (2 companies),

- Between a year and one and a half year ago: $12.50 \%$ (4 companies),

- Between one and a half year and two years ago: $9.38 \%$ (3 companies),

- Between two and three years ago: $25 \%$ (8 companies),

- Between three and five years ago: $21.80 \%$ (7 companies),

- More than five years ago: $21.80 \%$ (7 companies).

For companies that use them, which LMTs are helping them the most? The question was: "Which lean manufacturing techniques have helped (or are helping) you the most?"

Figure 4 presents the average of all numbers about lean manufacturing techniques that have helped the most companies in their process of production, such as money, time, number of workers, inventory, etc.

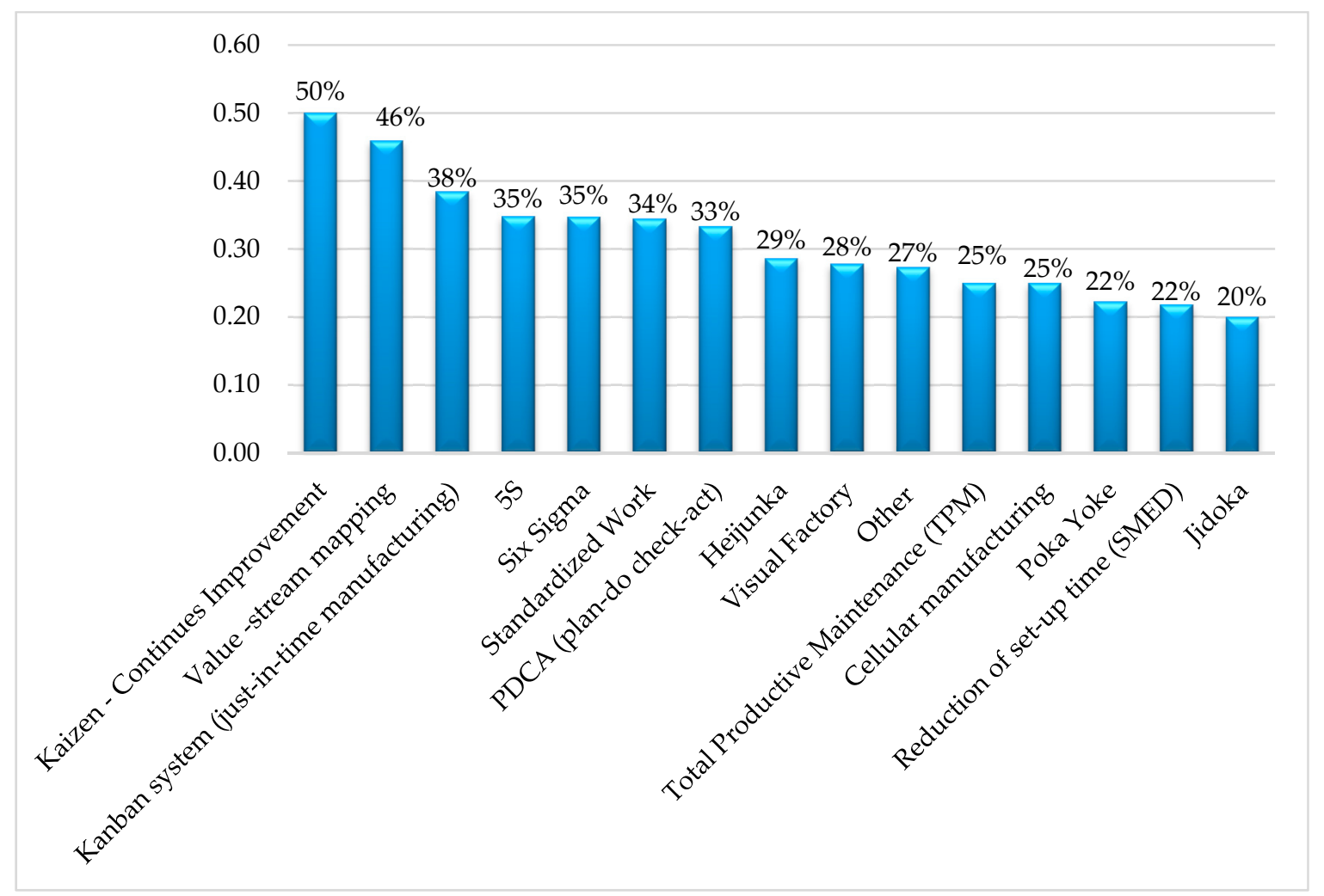

Figure 4. The average of all numbers about Lean Manufacturing Techniques (LMTs) that have helped the most companies.

The most helpful LMTs based on respondents are: Kaizen, value stream mapping, Kanban system, 5S, Six Sigma, standardized work, and so forth.

Selection of Basic Lean Tools for the Development of the Kosovo Model Regard to Industry 4.0

From a technological point of view, lean production can be regarded as a compliment to automation, some of the lean tools have more importance in those processes. Zuehlke [16] suggested that the complexity of the production system should be reduced by lean practices and stated that relying too much on technology cannot always improve the performance but may make the system 
more complicated. Some research has been performed to emphasize the interaction between lean manufacturing and Industry 4.0. Models have been proposed to integrate lean manufacturing and Industry 4.0 concerning supplier, costumer, and process as well as human and control factors. Veza et al. [17] carried out an analysis of global and local enterprises based on a literature review and questionnaires to develop a Croatian model of the innovative smart enterprise (HR-ISE model). In that study, a selection of six basic lean tools were made and foundations of the generic configuration of the HR-ISE model were defined.

In general, to successfully implement any management practice should often rely on organizational characteristics. Often, the most uncovered practices usually connected with lean production are: cellular manufacturing, bottleneck removal (production smoothing), continuous improvement programs, competitive benchmarking, cross-functional workforce, focused factory production, cycle time reductions, lot size reductions, just-in-time/continuous flow production, new process equipment/technologies, preventive maintenance, maintenance optimization, planning and scheduling strategies, pull system/Kanban, process capability measurements, quick changeover techniques, quality management programs, safety improvement programs, self-directed work teams, total quality management, re-engineered production process [7].

As mentioned earlier, the main reason for this investigation was to establish certain phases and steps for process and structural reorganization of Kosovo enterprises based on lean principles. Just-in-time, continuous improvement-Kaizen, flow orientation, standardized work, value stream management, pull system are the six most important lean tools for Croatian enterprises based on a synthesis of green application analysis and lean tools in Croatian enterprises [17] and application of Lean tools in 30 global enterprises [18]. Similarly, which lean tools are most used and helpful in Kosovo enterprises were investigated. From 95 enterprises, which have been analyzed, only 32 of them using lean manufacturing techniques. As is seen from Figure 4, the most used and helpful lean tools based on the response from the questionnaires are:

1. Kaizen-continuous improvement,

2. Kanban system-just-in-time,

3. Standardized work,

4. Six Sigma,

5. Total productive maintenance-TPM,

6. Value stream mapping,

7. Reduction of set-up time-SMED.

These seven lean tools are the most helpful and used in Kosovo enterprises, and represent basic tools for the Kosovo model of production system regard to Industry 4.0 and innovative smart enterprises.

\section{Conclusions}

As mentioned at the beginning, this investigation is the continuing process of our initiatives in preparation of Kosovo enterprises for the new age of industry-Industry 4.0. For that, the main purpose of this study was to select the most used and helpful lean tools. After analyses of data collected from companies, some conclusions have been drawn:

- The main reasons that companies do not use LMTS are: they are not much informed about lean manufacturing techniques ( $43.48 \%$ of responses), they understand lean manufacturing techniques but they are not informed how to use them (39.13\% of responses), they consider that adopting lean manufacturing techniques will not be beneficial (17.39\% of responses).

- The most helpful LMTs based on the response of respondents are Kaizen, value stream mapping, Kanban system, 5S, Six Sigma, standardized work.

- None of the companies has completely implemented principles, but in partial and limited level.

These facts represent the main problem in the journey of Kosovo manufacturing industries toward Industry 4.0. Industry 4.0 will not solve problems of mismanaged and weakly organized manufacturing 
systems. Its tools should have been applied to lean activities that are successfully performed before automatizing. Kaizen - continuous improvement, Kanban system-just-in-time, standardized work, Six Sigma, total productive maintenance-TPM, value stream mapping, and reduction of set-up time-SMED are the most used and helpful lean principles in Kosovo enterprises based on the respondents' answers (Figures 3 and 4). These seven basic lean tools are approximately the same as lean tools in Croatia [17]; according to research there are six lean tools: just-in-time, Kaizen, flow orientation, standardized work, value stream management, and pull system.

Therefore, the selection of seven basic lean tools was made, and foundations of the generic configuration of the Kosovo model regardingustry 4.0 (innovative smart enterprise) model are defined.

\section{References}

1. Holweg, M. The genealogy of lean production. J. Oper. Manag. 2007, 25, 420-437. [CrossRef]

2. Azemi, F.; Lujic, R.; Šimunović, G.; Maloku, B. Utilization and impact of ict on smes: The case study of the kosovo private sector at furniture and metalworking industry. In Proceedings of the International Multidisciplinary Scientific GeoConference Surveying Geology and Mining Ecology Management, Sofia, Bulgaria, 29 June-5 July 2017; Volume 17, pp. 751-758. [CrossRef]

3. Azemi, F.; Šimunović, G.; Lujić, R.; Tokody, D. Intelligent Computer-Aided resource planning and scheduling of machining operation. Procedia Manuf. 2019, 32, 331-338. [CrossRef]

4. Womack, J.P.; Jones, D.T.; Roos, D. The machine that changed the world. Bus. Horiz. 1992, 35, 81-82. [CrossRef]

5. Yingling, J.C.; Detty, R.B.; Sottile, J. Lean manufacturing principles and their applicability to the mining industry. Miner. Resour. Eng. 2000, 9, 215-238. [CrossRef]

6. Kumar, R.; Kumar, P.S. Strategy development for lean manufacturing implementation in a selected Manufacturing company. Int. J. Eng. Sci. 2014, 3, 51-57.

7. Shah, R.; Ward, P.T. Lean manufacturing: Context, practice bundles, and performance. J. Oper. Manag. 2003, 21, 129-149. [CrossRef]

8. Singh, B.; Garg, S.K.; Sharma, S.K. Lean can be a survival strategy during recessionary times. Int. J. Product. Perform. Manag. 2009. [CrossRef]

9. Melton, T. The Benefits of Lean Manufacturing. Chem. Eng. Res. Des. 2005. [CrossRef]

10. Morgen, J.M.; Liker, J.K. The Toyota Product Development System; Productivity Press: New York, NY, USA, 2006.

11. Liker, J.K.; Morgan, J.M. The toyota way in services: The case of lean product development. Acad. Manag. Perspect. 2006, 20, 5-20. [CrossRef]

12. Azemi, F.; Šimunović, G.; Luji, R.; Tokody, D.; Rajnai, Z. The Use of Advanced Manufacturing Technology to Reduce Product Cost. Acta Polytech. Hung. 2019, 16, 115-131. [CrossRef]

13. Johansson, L. Handbook on Green Productivity; Azian Productivity Organization: Tokyo, Japan, 2006.

14. Chakravorty, S.S. Six Sigma programs: An implementation model. Int. J. Prod. Econ. 2009. [CrossRef]

15. Slack, A.; Ho, S.; Forni, L.G. The management of acute renal failure. Medicine 2007. [CrossRef]

16. Zuehlke, D. SmartFactory-Towards a factory-of-things. Annu. Rev. Control 2010, 34, 129-138. [CrossRef]

17. Veza, I.; Mladenio, M.; Gjeldum, N. Selection of the basic lean tools for development of Croation model of innovative smart enterprise. Teh. Vjesn. 2016, 23, 1317-1324.

18. Netland, T.H. Exploring the phenomenon of company-specific Production Systems: One-best-way or own-best-way? Int. J. Prod. Res. 2012, 54, 1084-1097. [CrossRef]

Publisher's Note: MDPI stays neutral with regard to jurisdictional claims in published maps and institutional affiliations.

(C) 2020 by the authors. Licensee MDPI, Basel, Switzerland. This article is an open access article distributed under the terms and conditions of the Creative Commons Attribution (CC BY) license (http://creativecommons.org/licenses/by/4.0/). 